\title{
Analisis Prioritas Faktor-Faktor yang Mempengaruhi Minat Muzakki dalam Berzakat, Infaq dan Sedekah di Masa Pandemik Covid-19
}

\author{
Sifa Nursalimah*, Ifa Hanifia Senjiati \\ Prodi Hukum Ekonomi Syariah, Fakultas Syariah, Universitas Islam \\ Bandung, Indonesia. \\ *sifanursalimah55@gmail.com, ifa.wahyudin@gmail.com
}

\begin{abstract}
The presence of the covid-19 pandemic in Indonesia has had a significant impact on the declining Indonesia economy. However, in the midst of the covid-19 pandemic, the collection of ZIS at BAZNAS West Java actually increased by $23,85 \%$ in the first semester of 2020 when compared to the first semester 2019. Even though many people have lost their livelihoods. The increase in ZIS collection is influenced by several factor that influence muzakki's interest in tithing, infaq and alms, namely income, religiosity, knowledge and belief. The four factors have different values and influences. The purpose of this is to find out which of the four factors is a priority factor for muzakki's interest in fulfilling ZIS at BAZNAS West Java. The research method used is descriptive qualitative, with the type of field data. The data sources used are primary and secondary. Data collection techniques through observation, questionnaires, interviews and documentation. While the data analysis technique is using the AHP (Analyical Hierarchy Proces) method. The results of this study are that the general description of the income of muzakki's in BAZNAS West Java is the majority of ASN with income > Rp. 6.800.000, with a fairly high level of religiosity and good knowledge and belief in BAZNAS. While the priority factors of muzakki's interest in fulfilling ZIS are income $(0,317)$, religiosity (0.296), belief (0.194) and knowledge (0.193).
\end{abstract}

Keywords: Priority, Factors, Interest, ZIS.

Abstrak. Hadirnya pandemik covid-19 di Indonesia memberikan dampak yang cukup signifikan terhadap perekonomian Indonesia yang mengalami penurunan. Namun di tengah pandemik covid-19, penghimpunan ZIS di BAZNAS Jawa Barat justru mengalami peningkatan sebesar 23,85\% pada semester I tahun 2020 jika dibandingkan semester I tahun 2019. Padahal banyak masyarakat yang kehilangan mata pencahariannya. Peningkatan penghimpunan ZIS ini dipengaruhi oleh beberapa faktor yang mempengaruhi minat muzakki dalam berzakat, infaq dan sedekah yaitu pendapatan, religiusitas, pengetahuan dan kepercayaan. Keempat faktor tersebut mempunyai nilai dan pengaruh yang berbeda. Tujuan dari penelitian ini adalah untuk mengetahui mana dari ke empat faktor tersebut yang menjadi faktor prioritas minat muzakki dalam menunaikan ZIS di BAZNAS Jawa Barat. Metode penelitian yang digunakan adalah deskriptif kualitatif, dengan jenis data lapangan. Sumber data yang digunakan yaitu primer dan sekunder. Teknik pengumpulan data melalui observasi, kuesioner, wawancara dan dokumentasi. Sedangkan teknik analisis data yaitu menggunakan metode AHP (Analytical Hierarchi Process). Hasil penelitian ini adalah bahwa gambaran umum pendapatan muzakki di BAZNAS Jawa Barat mayoritas ASN dengan pendapatan > Rp. 6.800.000, dengan tingkat religiusitas yang cukup tinggi dan memiliki pengetahuan dan kepercayaan yang baik terhadap BAZNAS. Sedangkan faktor prioritas minat muzakki dalam menunaikan ZIS adalah pendapatan $(0,317)$, religiusitas $(0,296)$, kepercayaan $(0,194)$ dan pengetahuan $(0,193)$.

Kata Kunci: Prioritas, Faktor, Minat, ZIS. 


\section{A. Pendahuluan}

Indonesia saat ini sedang diuji dengan hadirnya virus covid-19 yang seketika mengubah tatanan kehidupan dunia. Salah satu dampak dari adanya virus ini yaitu terhadap sektor perekonomian Indonesia yang mengalami penurunan. Maka, pemerintah terus mengupayakan agar perekonomian Indonesia kembali berjalan normal serta masyarakat terdampak covid-19 dapat terbantu. Salah satu solusi yang diambil pemerintah adalah dengan memanfaatkan pengumpulan harta zakat, infaq dan sedekah yang terdapat di lembaga pengelola zakat di seluruh Indonesia. Hal tersebut tertuang dalam Fatwa MUI No. 23 tahun 2020 tentang Pemanfaatan Harta Zakat, Infaq dan Sedekah Untuk Penanggulangan Wabah Covid-19 dan Dampaknya. (Bona 2020).

Menyikapi pandemik covid-19 tersebut, masyarakat turut ambil bagian untuk saling bantu membantu saudaranya yang kesulitan dengan berbagai cara. Salah satunya yaitu dengan menunaikan zakat, infaq dan sedekah ke lembaga pengelola zakat. Zakat memiliki arti suci, bersih, tumbuh dan berkah. Sedangkan menurut istilah yaitu mengeluarkan sebagian harta tertentu yang diwajibkan Allah SWT untuk diserahkan kepada orang-orang yang berhak menerimanya dengan syarat-syarat tertentu. (Harisah, et al. 2021)

Adapun mengenai perintah untuk melaksanakan zakat, Allah SWT telah berfirman dalam Q.S At-Taubah Ayat [9]: 103, yang berbunyi:

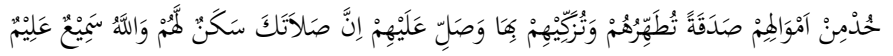

Artinya:

Ambillah zakat dari harta mereka, guna membersihkan dan menyucikan mereka dan berdo 'alah untuk mereka. Sesunggguhnya do'amu itu (menumbuhkan) ketenteraman jiwa bagi mereka. Allah Maha Mendengar, Maha Mengetahui. (Departemen Agama RI 2016)

Infaq berasal dari kata anfaqa yang artinya keluar. Menurut terminologi, infaq berarti mengeluarkan sebagian harta atau pendapatan untuk sesuatu yang diperintahkan ajaran Islam dengan tujuan untuk mendapatkan ridha Allah SWT. (Khairina 2019). Sedangkan sedekah berasal dari kata shadaqah yang berarti jujur atau benar. Menurut terminologi, sedekah adalah memberikan sesuatu yang dilakukan oleh seseorang untuk diberikan kepada orang lain karena mengharapkan keridhaan dan pahala dari Allah SWT dan tidak mengharapkan suatu jasa atau imbalan sebagai penggantinya. (Uyun 2015). Sedekah sama dengan infaq termasuk hukum dan ketentuannya. Hanya saja, infaq berkaitan dengan materi/harta, sedangkan sedekah tidak hanya berupa harta tetapi non harta seperti memberikan senyuman tulus, menyingkirkan duri di jalan, dan lain-lain.

Dasar hukum infaq dan sedekah, terdapat dalam Q. S Al-Baqarah [2]: 195 dan Q.S Yusuf [12]: 88, sebagai berikut:

Artinya:

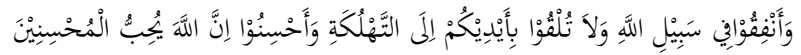

"Dan infaqkanlah (hartamu) di jalan Allah, dan janganlah kamu jatuhkan (dirimu sendiri) ke dalam kebinasaan dengan tangan sendiri dan berbuat baiklah. Sungguh Allah menyukai orang-orang yang berbuat baik”. (Q. S Al-Baqarah [2]: 195) (Departemen Agama RI 2016)

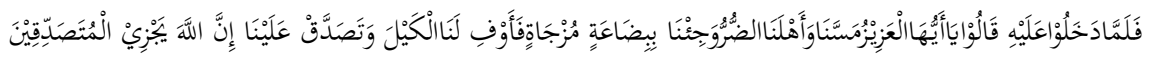

Artinya:

Maka ketika mereka masuk ke (tempat) Yusuf, mereka berkata: "Hai Al Aziz, kami dan keluarga kami telah ditimpa kesengsaraan dan kami datang membawa barang-barang yang tak berharga, maka penuhilah jatah (gandum) untuk kami, dan bersedekahlah kepada kami. Sesungguhnya Allah memberi balasan kepada orang-orang yang bersedekah. (Q.S Yusuf [12]: 88). (Departemen Agama RI 2016)

Zakat, infaq dan sedekah merupakan institusi hukum Islam yang tidak hanya sebagai sebuah kewajiban sebagai seorang muslim, tetapi bisa digunakan untuk mensejahterakan umat. Maka perlu adanya pengelolaan yang baik agar pendistribusiannya tepat sasaran kepada orangorang yang berhak menerimanya. Pengelolaan zakat sendiri merupakan kegiatan perencanaan, pengorganisasian, pelaksanaan dan pengawasan terhadap pengumpulan dan pendistribusian serta pendayagunaan zakat. (Triyawan dan Aisyah 2016). Dalam pengelolaannya, diperlukan 
pula pengukuran terhadap kinerja lembaga zakat agar lembaga tersebut bisa terus memperbaiki kinerja organisasinya. Sehingga dapat tumbuh menjadi lembaga yang sehat dengan kepercayaan publik yang baik. (Akbar, Senjiati dan Anshori 2020)

Adanya rasa semangat saling membantu dan membangun solidaritas melawan pandemik covid-19 dengan cara berzakat, infaq dan sedekah ini terlihat dari adanya peningkatan penghimpunan zakat, infaq dan sedekah di BAZNAS RI pada tahun 2020 sebesar 30\%, serta di BAZNAS Provinsi Jawa Barat pada semester I tahun 2020 sebesar 23,85\%. (Amanda 2020). Peningkatan penghimpanan zakat, infaq dan sedekah di BAZNAS Jawa Barat tersebut, dapat dilihat pada tabel di bawah ini:

Tabel 1. Penghimpunan Zakat Berdasarkan Jenis Sumber Dana Semester I Tahun 2019-2020

\begin{tabular}{|c|l|l|l|}
\hline No. & Jenis Penerimaan & \multicolumn{1}{|c|}{$\mathbf{2 0 1 9}$} & \multicolumn{1}{|c|}{$\mathbf{2 0 2 0}$} \\
\hline 1. & Zakat Profesi & 12.324 .126 .844 & 14.532 .127 .351 \\
\hline 2. & Zakat Maal & 440.064 .140 & 688.250 .638 \\
\hline 3. & Zakat Fitrah & 2.311 .750 & 9.956 .284 \\
\hline 4. & Infaq Terikat & 18.410 .023 & 601.728 .439 \\
\hline 5. & Infaq Tak Terikat & 185.931 .429 & 231.971 .024 \\
\hline 6. & Fidyah & 900.000 & 2.760 .000 \\
\hline 7. & TOTAL & $\mathbf{1 2 . 9 7 1 . 7 4 9 . 1 8 6}$ & $\mathbf{1 6 . 0 6 6 . 7 9 3 . 7 3 6}$ \\
\hline
\end{tabular}

Sumber: Laporan Tahunan BAZNAS Jawa Barat Semester I 2019-2020

Berdasarkan tabel tersebut, terlihat adanya peningkatan penghimpunan zakat, infaq dan sedekah pada semester I tahun 2020 yaitu sebesar 16.066.793.736 dibanding semester I tahun 2019 yang hanya terhimpun sebesar Rp. 12.971.749.186. Peningkatan penghimpunan zakat, infaq dan sedekah tersebut berhubungan dengan faktor-faktor yang mempengaruhi minat muzakki dalam berzakat, infaq dan sedekah. Adapun faktor-faktor yang mempengaruhi minat muzakki dalam berzakat, infaq dan sedekah yaitu pendapatan, religiusitas, pengetahuan dan kepercayaan. (Rakhmania 2018). Minat diartikan sebagai kondisi dan keadaan seseorang yang mempunyai ketertarikan terhadap sesuatu hal disertai keinginan untuk mempelajari dan mengetahui lebih lanjut. (Tho'in dan Marimin 2019).

Di BAZNAS Jawa Barat sendiri, keempat faktor tersebut mempunyai nilai dan pengaruh yang berbeda-beda, yaitu hasil uji empiris pengaruh pengetahuan terhadap minat muzakki untuk berzakat menunjukan bahwa pengetahuan tidak berpengaruh signifikan terhadap minat muzakki untuk berzakat dengan besaran koefisien sebesar 3,7\%. Kemudian hasil uji empiris pengaruh religiuitas terhadap minat muzakki untuk berzakat menunjukan bahwa religiusitas berpengaruh positif dan signifikan terhadap minat muuzakki untuk berzakat dengan besaran koefisien sebesar 39,7\%. (Mirawati, Tanjung dan Arif 2019). Adapun faktor pendapatan, secara parsial tidak berpengaruh terhadap minat membayar zakat. (Tho'in dan Marimin 2019). Sedangkan faktor kepercayaan berpengaruh signifikan terhadap minat muzakki membayar zakat. (Anggita dan Yuliafitri 2020)

Berdasarkan penjelasan di atas, peneliti tertarik untuk melakukan leveling mana dari keempat faktor tersebut yang menjadi prioritas minat muzakki dalam berzakat, infak dan sedekah menggunakan metode AHP (Analytical Hierarchi Process), dengan rumusan masalah: Bagaimana gambaran umum pendapatan, religiusitas, pengetahuan dan kepercayaan muzakki di BAZNAS Jawa Barat? Bagaimana analisis prioritas faktor-faktor yang mempengaruhi minat muzakki dalam berzakat, infaq dan sedekah di masa pandemik covid-19?

Adapun tujuan dari penelitian ini, yaitu:

1. Untuk mengetahui gambaran umum pendapatan, religiusitas, pengetahuan dan kepercayaan muzakki di BAZNAS Jawa Barat.

2. Untuk mengetahui prioritas faktor-faktor yang mempengaruhi minat muzakki dalam berzakat, infaq dan sedekah di masa pandemik covid-19. 


\section{B. Metodologi}

\section{Pendekatan Penelitian}

Penelitian ini menggunakan metode penelitian kualiatif deskriptif. Penelitian kualitatif adalah penelitian yang digunakan untuk memahami permasalahan manusia atau realita sosial dengan menciptakan gambaran secara menyeluruh dan kompleks yang disajikan dengan kata-kata, melaporkan pandangan terperinci yang bersumber dari para informan serta dilakukan dalam latar (setting) yang alamiah. (Walidin, Saifullah dan Tabrani 2015). Penelitian kualitatif ini bersifat deskriptif karena tidak menggunakan perhitungan atau angka. Sedangkan pendekatan deskriptif bertujuan untuk membuat deskripsi secara akurat, faktual dan sistematis mengenai fakta dan sifat populasi atau suatu objek tertentu. (Heriawan 2016)

\section{Jenis Data Penelitian}

Jenis data yang digunakan pada penelitian ini adalah data lapangan, karena peneliti memperoleh data secara langsung di lapangan dari responden melalui observasi, wawancara dan kuesioner.

\section{Sumber Data Penelitian}

Sumber data yang digunakan pada penelitian ini, yaitu data primer, merupakan data asli atau data baru yang memiliki sifat up to date (Rinaldi dan Hidayah 2017), diperoleh dari hasil kuesioner yang disebarkan kepada responden yaitu muzakki BAZNAS Jawa Barat dan wawancara kepada pihak BAZNAS Jawa Barat. Sedangkan data sekunder, merupakan data dari berbagai sumber yang telah ada, diperoleh dari jurnal, buku, dokumentasi instansi terkait seperti laporan tahunan dan website instansi yang terkait dengan penelitian.

\section{Teknik Pengumpulan Data}

Teknik pengumpulan data yang digunakan dalam penelitian ini, yaitu observasi, kuesioner, wawancara dan dokumentasi. Observasi adalah kegiatan yang dilakukan secara sistematis, terencana, terarah pada suatu tujuan dengan mengamati dan mencatat perilaku satu atau sekelompok orang dalam kehidupan sehari-hari. (Walidin, Saifullah dan Tabrani 2015). Kuesioner adalah cara pengumpulan data dengan melakukan penyebaran daftar pertanyaan kepada responden yang menjadi subjek penelitian. (Abdullah 2015). Wawancara dilakukan untuk mendapatkan informasi mengenai gambaran umum tingkat pendapatan, religiusitas, pengetahuan dan kepercayaan muzakki BAZNAS Jawa Barat. Sedangkan dokumentasi adalah alat pengumpulan data yang digunakan untuk mencari, mengenal hal-hal yang bersumber dari majalah, catatan, surat kabar, laporan tahunan dan lain-lain. (Hasanah 2017), dilakukan untuk memperoleh data tentang profil lembaga serta segala sesuatu yang berkaitan dengan objek penelitian.

\section{Teknik Analisis Data}

Teknik analisis data yang digunakan dalam penelitian ini adalah dengan metode AHP (Analytical Hierchy Process), yaitu sebuah teori pengukuran melalui perbandingan berpasangan yang bergantung kepada penilaian para pakar yang dapat menghasilkan skala prioritas. (Saaty 2008)

\section{Hasil dan Pembahasan}

Gambaran Umum Pendapatan, Religiusitas, Pengetahuan dan Kepercayaan Muzakki di BAZNAS Jawa Barat

Hasil penelitian ini berdasarkan atas wawancara bersama Bpk. Kiki selaku Bagian Kesekretariatan dari Divisi SDM, Administrasi dan Umum di BAZNAS Jawa Barat. Menurut hasil wawancara bersama Bpk. Kiki, bahwa:

1. Tingkat pendapatan Muzakki BAZNAS Provinsi Jawa Barat sebagian besar memiliki pendapatan di atas Rp. 6.800.000/bulan, dengan jenis pekerjaan mayoritas sebagai Pejabat dan ASN (Aparatur Sipil Negara). Adapun nisab zakat pendapatan yang harus dikeluarkan oleh muzakki BAZNAS Provinsi Jawa Barat bila dilihat dari perhitungan zakat kontemporer yaitu dengan menggunakan hitungan zakat emas sebesar $85 \mathrm{gr} /$ tahun dan kadar sebesar 2,5\% 
Bila harga emas seharga Rp. 800.000/gr, maka nisab zakat pendapatan dalam 1 tahun adalah:

Rp. $800.000 \times 85$ gr emas = Rp. 68.000.000,-

Penghasilan muzakki BAZNAS Jawa Barat \pm Rp. 6.800.000/bulan atau Rp. 81.600.000/tahun. Artinya penghasilan tersebut sudah wajib zakat karena sudah melebihi nisab 1 tahun. Maka, nisab zakat pendapatan muzakki BAZNAS Jawa Barat, yaitu:

Rp. $81.600 .000 \times 2,5 \%=$ Rp. $2.040 .000 /$ tahun, sedangkan perbulannya yaitu sebesar Rp. 170.000. Dengan membayar zakat yang dilakukan perbulan dapat meringankan muzakki untuk membayar zakat pendapatannya secara rutin.

2. Tingkat religiusitas yang dimiliki oleh muzakki BAZNAS Jawa Barat, sebagian besar memiliki religiusitas yang cukup tinggi. Hal tersebut terlihat dari konsistensi muzakki dalam menunaikan zakat, infaq dan sedekah di BAZNAS Jawa Barat. Dengan mereka tetap konsisten membayar zakat, itu berarti mereka memiliki keyakinan terhadap agamanya serta selalu berusaha mematuhi perintah tuhannya yang diwujudkan dengan menjalankan kewajiban ia sebagai seorang muslim untuk menunaikan zakat.

3. Tingkat pengetahuan muzakki BAZNAS Jawa Barat telah memiliki pengetahuan mengenai zakat, infaq dan sedekah. Mereka mengetahui bahwa zakat hukumnya wajib dan dengan infaq sedekah dapat menciptakan kesejahteraan umat. Mereka pun mengetahui bahwa kekayaan yang mereka miliki hanyalah titipan dan terdapat hak orang lain di dalamnya.

4. Tingkat kepercayaan muzakki kepada BAZNAS Provinsi Jawa Barat sangat besar. Hal ini karena setiap muzakki yang berdonasi selalu direkap mulai dari biodatanya, dikirimkan laporannya serta selalu diingatkan agar mereka menunaikan zakat, infaq dan sedekah. Selain itu, BAZNAS Jawa Barat memiliki kelebihan yang dapat meningkatkan kepercayaan muzakki serta masyarakat untuk berzakat, infaq dan sedekah di BAZNAS Jawa Barat, diantaranya: BAZNAS Jawa Barat merupakan lembaga pemerintah yang memiliki legalitas yang jelas, mendapatkan predikat A sesuai syariah sebagai lembaga pengelola zakat dari Kementerian Agama Republik Indonesia pada tahun 2018, selalu mengadakan audit setiap semester dengan audit ISO (Internasional Standardization Organization), sehingga sudah sesuai standar Internasional, menerbitkan laporan tahunan agar selalu terjaga transparansi kepada publik, dan lain-lain.

\section{Analisis Prioritas Faktor-Faktor Yang Mempengaruhi Minat Muzakki Dalam Berzakat, Infaq dan Sedekah di Masa Pandemik Covid-19}

Faktor atau kriteria yang dinilai dapat mempengaruhi minat muzakki dalam menunaikan ZIS, yaitu pendapatan, religiusitas, pengetahuan dan kepercayaan. Untuk menganalisis prioritas faktor tersebut, yaitu dengan metode AHP (Analytical Hierarchy Process) dan pengolahan data menggunakan aplikasi expert choise 11. Aplikasi expert choise 11 merupakan aplikasi yang digunakan oleh para pengambil keputusan dimana aplikasi ini sebagai alat dalam membantu menentukan keputusan tertentu. (Juliani, Srisusilawati dan Hidayat 2020). Langkah-langkah untuk mencari prioritas faktor tersebut, adalah sebagai berikut:

1. Mengidentifikasi Masalah

Pada tahap ini, dilakukan identifikasi masalah dengan cara membuat bagan struktur hieraki dari permasalahan yang ada serta menentukan tujuan, kriteria dan alternatifnya, seperti pada gambar di bawah ini: 


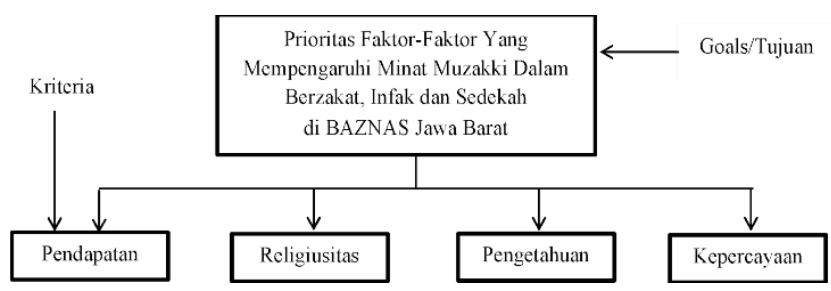

Gambar 1. Struktur Hierarki

2. Matriks Perbandingan Berpasangan Antar Kriteria

Pada tahap ini, dilakukan perbandingan terhadap kriteria-kriteria yang telah ada secara berpasangan dengan nilai-nilai perbandingan yang diperoleh dari hasil kuesioner kepada 103 muzakki BAZNAS Jawa Barat. Data hasil kuesioner tersebut dimasukkan ke dalam aplikasi expert choise 11, seperti pada gambar di tabel ini:

Tabel 2. Matriks Perbandingan Berpasangan Antar Kriteria

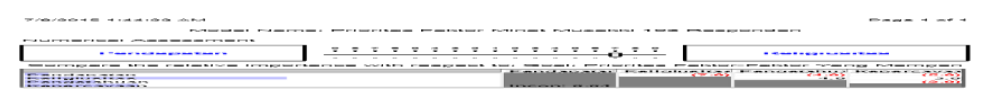

3. Sintesis Matriks Perbandingan Kriteria

Setelah membuat matriks perbandingan berpasangan, dilanjutkan dengan membuat tabel sintesis yang menjadi dasar dalam mendapatkan gambaran prioritas faktor. Ada beberapa langkah dalam melakukan sintesis matriks perbandingan kriteria, yaitu:

1. Melakukan penjumlahan terhadap nilai dari setiap kolom matriks.

2. Melakukan pembagian terhadap setiap kolom matriks dengan total kolom matriks agar dapat memperoleh normalisasi matriks.

3. Melakukan penjumlahan nilai dari setiap baris dibagi dengan total kriteria agar dapat memperoleh nilai rata-rata.

Hasil matriks perbandingan berpasangan antar variabel dari 103 responden akan dibentuk satu kesatuan data agar dapat melanjutkan perhitungan AHP, yaitu sebagai berikut:

Tabel 3. Hasil Combined Matriks Perbandingan Berpasangan

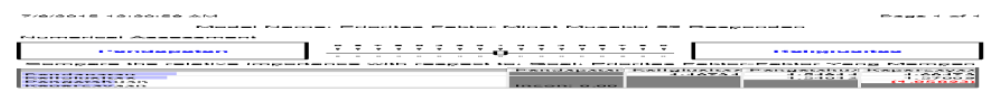

4. Menghitung Konsistensi

Untuk menghitung konsistensi, digunakan rumus sebagai berikut:

1. Perhitungan CI (Consistency Indeks)

$\mathrm{CI}=($ Lamdamaks $-\mathrm{n}) /(\mathrm{n}-1)$

$\mathrm{n}=$ banyak kriteria

2. Perhitungan $\mathrm{CR}$ (Consistency Ratio)

$\mathrm{CR}=\mathrm{CI} / \mathrm{IR}$

$\mathrm{CR}=$ Consistency Ratio

$\mathrm{CI}=$ Consistency Indeks

IR = Indeks Random Consistency

Nilai IR, dapat dilihat pada tabel di bawah ini: 
Tabel 4. Daftar Indeks Random Consistency (IR)

\begin{tabular}{|c|c|c|c|c|c|}
\hline $\mathrm{N}$ & 1 & 2 & 3 & 4 & 5 \\
\hline $\mathrm{IR}$ & 0,00 & 0,00 & 0,58 & 0,90 & 1,12 \\
\hline
\end{tabular}

\section{Memeriksa konsistensi hirarki}

Konsistensi hirarki (CR) memiliki nilai $\leq \leq 0,1$, yang artinya hasil perhitungan dinyatakan benar. Jika nilai CR lebih dari 10\% atau 0,1 maka penilaian data judgement harus dilakukan perbaikan.

Adapun nilai CR dalam penelitian ini tidak dilakukan perhitungan manual, melainkan menggunakan aplikasi expert choice 11 dimana hasilnya

menunjukan bahwa nilai CR sebesar $0,00 \leq \leq 0,1$ yang terdapat pada tabel 3 di atas. Dengan demikian, hasil perhitungan dapat dinilai konsisten.

5. Menentukan Bobot Perbandingan Berpasangan Antar Kriteria

Setelah melakukan penggabungan matriks antar kriteria, maka dihasilkan normalisasi matriks sehingga diketahui bobot dari masing-masing kriteria, sebagai berikut:

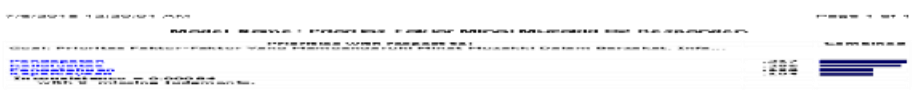

Gambar 2. Normalisasi Matriks Perbandingan Berpasangan Antar Kriteria

Berdasarkan normalisasi matriks di atas, terlihat bahwa kriteria pendapatan memiliki bobot 0,317, religiuistas 0,296, pengetahuan 0,193 dan kepercayaan 0,194.

6. Hasil Akhir Penilaian AHP dan Analisis Prioritas Faktor

Setelah diketahui bobot dari masing-masing kriteria, maka dihasilkan keseluruhan perhitungan AHP, sebagai berikut:

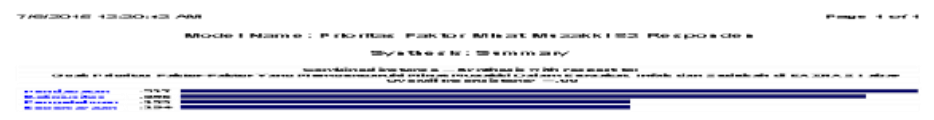

Gambar 3. Hasil Synthesis with Respect to Goal

Berdasarkan gambar di atas, menunjukan bahwa yang menjadi priotitas faktor yang mempengaruhi minat muzakki dalam berzakat, infaq dan sedekah di BAZNAS Jawa Barat, lebih cenderung kepada faktor pendapatan (bobot 0,317), diikuti oleh prioritas kedua yaitu faktor religiusitas (bobot 0,296), prioritas ketiga yaitu kepercayaan (bobot 0,194 ) dan prioritas ke empat yaitu pengetahuan (bobot 0,193). 
Adapun analisis terhadap faktor-faktor yang menjadi prioritas minat berzakat, infaq dan sedekah, yaitu:

1. Pendapatan menjadi prioritas utama dengan bobot sebesar 0,317, karena secara umum muzakki BAZNAS Provinsi Jawa Barat mayoritas berasal dari ASN yang terdapat di lingkungan Pemerintahan Provinsi Jawa Barat yang memiliki pendapatan di atas Rp. 6.800.000/bulan. Selain itu, muzakki lain berasal dari lingkungan UPZ di lingkungan instansi pemerintahan lainnya, seperti Kanwil Kemenag Jawa Barat, RUSD Al-Ihsan dan lingkungan UPZ Universitas Padjadjaran. Adapun rincian pembagian muzakki BAZNAS Jawa Barat, adalah sebagai berikut:

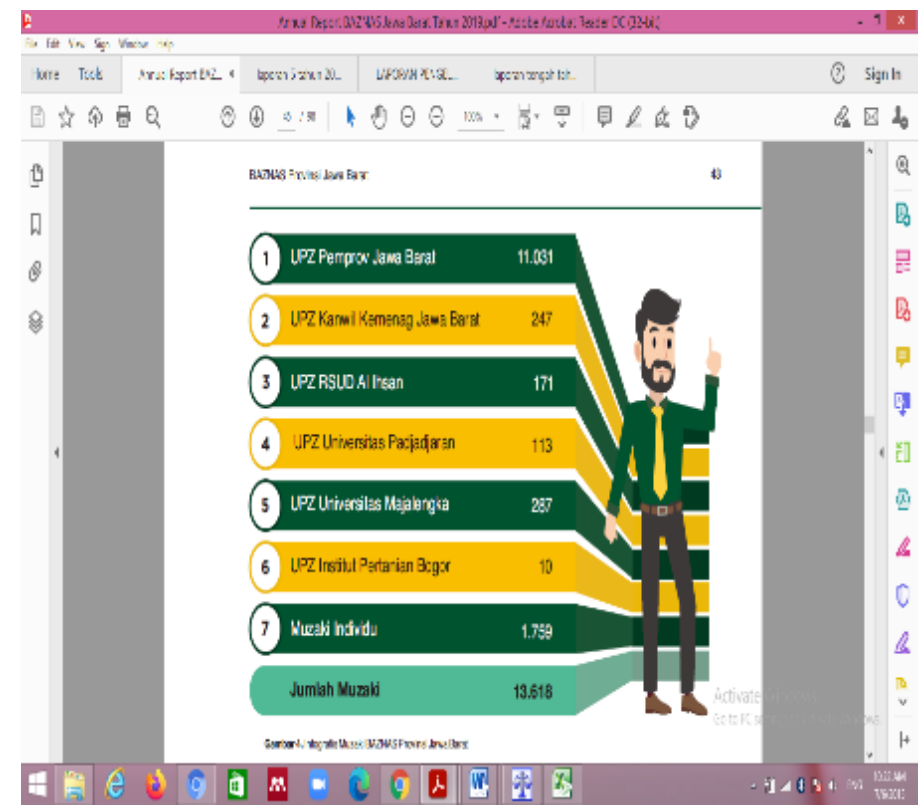

Sumber: Laporan Tahunan BAZNAS Provinsi Jawa Barat Tahun 2019.

Gambar 4. Infografis Muzakki BAZNAS Jawa Barat Tahun 2019

Selain itu, dengan sistem pembayaran yang dilakukan perbulan akan lebih meringankan muzakki untuk membayar zakat secara rutin, sehingga muzakki tidak terbebani dengan pembayaran zakat yang nominalnya besar sekaligus.

2. Religiusitas menjadi prioritas kedua dengan bobot sebesar 0,296, karena muzakki BAZNAS Jawa Barat memiliki konsistensi yang cukup tinggi dalam menunaikan zakat, infaq dan sedekah di BAZNAS Jawa Barat. Hal ini terlihat dari pertumbuhan penghimpunan zakat, infaq dan sedekah dari tahun 2015-2019, sebagai berikut: 


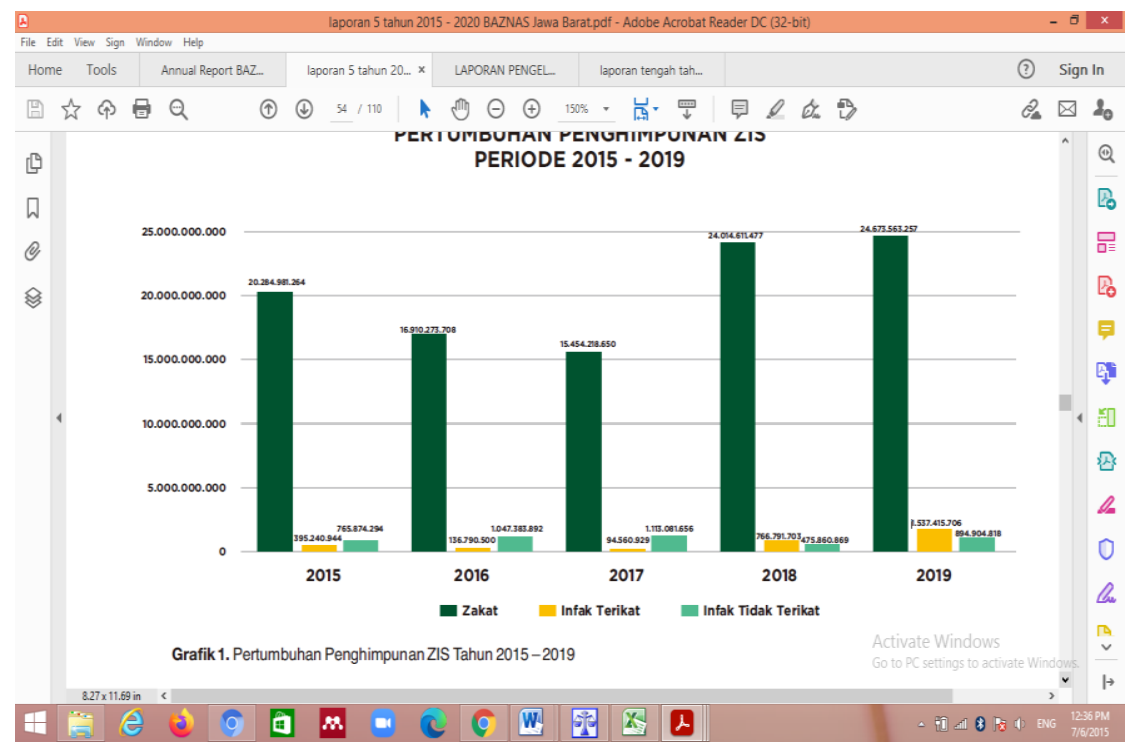

Sumber: Laporan Tahunan BAZNAS Provinsi Jawa Barat Tahun 2019.

Gambar 5. Pertumbuhan Penghimpunan ZIS Tahun 2015-2019

Gambar di atas menunjukan bahwa muzakki BAZNAS mempunyai keyakinan dan kepercayaan yang kokoh terhadap tuhan dan agamanya yang salah satunya diwujudkan dengan konsisten membayar zakat. Terlebih lagi seperti keadaan pandemik covid-19 saat ini, dimana timbul faktor diluar ekonomi yang mendorong mereka untuk menunaikan ZIS, seperti ketaatan atau keyakinan bahwa dengan sedekah akan menolak bala dan Allah akan mengganti dengan nilai yang lebih besar.

Selain itu, religiusitas muzakki BAZNAS Jawa Barat terlihat dari adanya peningkatan penghimpunan ZIS di semester I tahun 2019 dan 2020, sebagai berikut:

Tabel 5. Penghimpunan ZIS Semester I Tahun 2019-2020

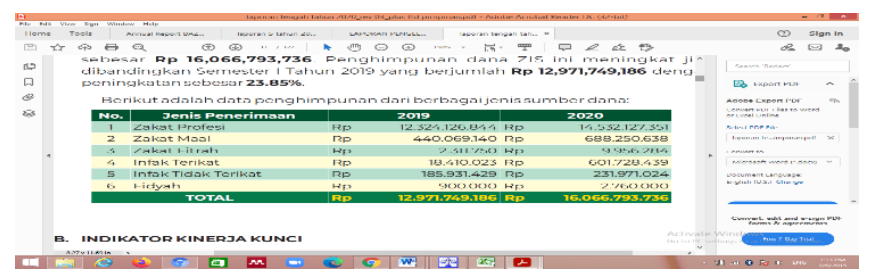

Sumber: Laporan Tahunan BAZNAS Jawa Barat Semester I Tahun 2019-2020

Berdasarkan tabel di atas, terjadi kenaikan penghimpunan ZIS di semester I tahun 2020 yaitu sebesar 23,85\% dibanding tahun 2019. Dimana di tahun ini awal terjadinya pandemik covid-19 yang menimbulkan dampak yang cukup signifikan terhadap perekonomian Indonesia yang mengalami penurunan, tetapi muzakki BAZNAS Jawa Barat masih tetap konsisten untuk menunaikan zakat, infaq dan sedekah.

3. Kepercayaan menjadi prioritas ketiga dengan bobot sebesar 0,194, karena BAZNAS Jawa Barat mempunyai kelebihan dan program yang dapat meningkatkan kepercayaan masyarakat terhadap BAZNAS. Selain untuk mendatangkan muzakki baru, BAZNAS Jawa Barat melakukan maintenance kepada muzakki lama untuk kembali berdonasi dengan berbagai cara. Yang dilakukan oleh tim penghimpunan adalah dengan pendekatan komunikasi yang baik dengan muzakki, layanan broadcast, email, chat khusus WA, jemput donasi dan layanan lainnya. Hal tersebut 
dapat mendorong masyarakat untuk menunaikan zakat, infaq dan sedekah di BAZNAS Jawa Barat. Sehingga pertumbuhan jumlah muzakki dan UPZ mengalami peningkatan setiap tahunnya, seperti pada gambar di bawah ini:

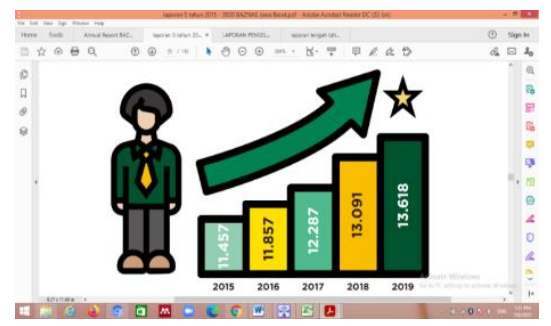

Gambar 6. Infografis Pertumbuhan Muzakki BAZNAS

Jawa Barat Tahun 2015-2019

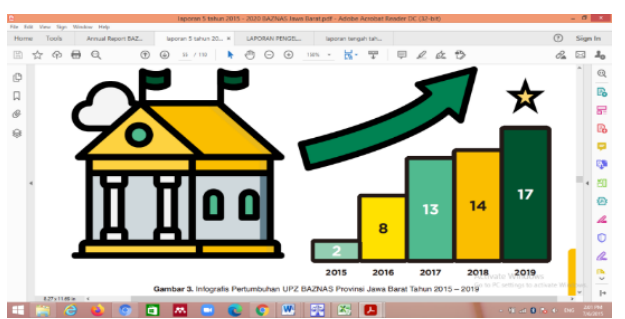

Sumber: Laporan Tahunan BAZNAS Jawa Barat Tahun 2015-2020

Gambar 7. Infografis Pertumbuhan UPZ BAZNAS

Jawa Barat Tahun 2015-2019

4. Pengetahuan menjadi prioritas keempat dengan bobot sebesar 0,193, mempunyai selisih 0,001 dengan faktor kepercayaan. Dapat di artikan bahwa faktor pengetahuan dengan faktor kepercayaan sama saja, karena mempunyai bobot nilai yang tidak signifikan. Walaupun muzakki kurang mengetahui nominal zakat yang harus dibayarkan, tetapi mereka tetap memiliki kemauan untuk menunaikan zakat.

\section{Kesimpulan}

Berdasarkan pembahasan dan hasil analisis mengenai prioritas faktor-faktor yang mempengaruhi minat muzakki dalam berzakat, infaq dan sedekah di masa pandemik covid-19, maka kesimpulan dari penelitian ini adalah:

1. Gambaran umum mengenai pendapatan, religiusitas, pengetahuan dan kepercayaan muzakki di BAZNAS Jawa Barat yaitu: muzakki BAZNAS Jawa Barat memiliki pendapatan di atas Rp. 6.800.000/bulan dengan jenis pekerjaan mayoritas sebagai Pejabat dan ASN (Aparatur Sipil Negara). Tingkat religiusitas muzakki BAZNAS Jawa Barat cukup tinggi, ini terlihat dari konsistensi muzakki dalam menunaikan zakat, infaq dan sedekah di BAZNAS Jawa Barat. Selain itu, muzakki BAZNAS Jawa Barat sudah memiliki pengetahuan mengenai zakat, infaq dan sedekah serta memiliki kepercayaan yang sangat besar terhadap BAZNAS Jawa Barat.

2. Analisis prioritas faktor-faktor yang mempengaruhi minat muzakki dalam berzakat, infaq dan sedekah di masa pandemic covid-19, adalah pendapatan $(0,317)$, religiusitas $(0,296)$, kepercayaan $(0,194)$ dan pengetahuan $(0,193)$. 


\section{Acknowledge}

Penulis mengucapkan terima kasih kepada Ibu dan Bpk. Dosen pembimbing serta seluruh pihak yang telah membantu terlesaikannya peneltian ini.

\section{Daftar Pustaka}

[1] Abdullah, M. (2015). Metode Penelitian Kuantitatif. Yogyakarta: Aswaja Pressindo.

[2] Akbar, Refki Kurniadi., Ifa Hanifia Senjiati., \& Arif Rijal Anshori. (2020). Analisis Efisiensi Kinerja BAZNAS Kota Bandung Dalam Pengelolaan Dana Zakat Menggunakan Metode Data Envelopment Analysis. Prosiding Hukum Ekonomi Syariah, Vol. 6 No. 2.

[3] Amanda, G. (2020, Januari Jumat). Masa Pandemik 2020, Penghimpunan Baznas Naik 30 Persen. Dipetik Maret Jumat, 2021, dari republika.co.id: https://www.republika.co.id/berita/qm91di423/masa-pandemi-2020-penghimpunanbaznas-naik-30-persen

[4] Anggita, A., \& Yuliafitri, I. (2020). Pengaruh Pengetahuan, Kepercayaan dan Pelayanan Lembaga Amil Zakat Terhadap Minat Membayar Zakat di Lembaga Amil Zakat. Jurnal ISEI: Accounting Review, Vol. IV No. 1.

[5] Bona, M. F. (2020, April Jumat). Fatwa MUI: Zakat Boleh Tangani Covid-19. Dipetik Juni Minggu, 2021, dari https://www.beritasatu.com/nasional/624959fatwa-mui-zakat-bolehuntuk-tangani-covid19,

[6] Departemen Agama RI. (2016). Al-Quran Tajwid dan Terjemah. Bandung: CV Penerbit Diponegoro.

[7] Harisah, Hoironi, Sa'adah, M., \& Jalil, A. (2021). Peran Zakat Dalam Pemulihan Ekonomi Saat Pandemi Covid-19. Syar'ie, Vol. 4 No. 1.

[8] Hasanah, U. (2017). Peningkatan Hasil Belajar Mata Pelajaran Fikih Melalui Penerapan Metode PQRST (Preview, Question, Read, Summarize, Test) Peserta Didik Kelas V di MI Ismaria Al-Qur'aniyah Islamiyah Raja Basa Bandar Lampung Tahun Pelajaran 2016/2017. Al-Tadzkiyyah: Jurnal Pendidikan Islam, Vol. 8 No. 1.

[9] Heriawan, S. (2016). Pola Komunikasi Kelompok Pada Komunitas Scooter "Vespa" Dalam Menjalin Hubungan Solidaritas (Studi Deskriptif Kualitatif Pada Komunitas Ikatan Scooter Wonogiri di Wonogiri. Naskah Publikasi Fakultas Komunikasi dan Informatika Universitas Muhammadiyah Surakarta.

[10] Juliani, G. P., Srisusilawati, P., \& Hidayat, Y. R. (2020). Giri Putri Juliani, dkk, Analisis Faktor-Faktor Prioritas Minat Konsumen dalam Memilih Hotel Syariah di Kota Bandung. Prosiding Hukum EKonomi Syariah, Vol.6 No. 2.

[11] Khairina, N. (2019). Analisis Pengelolaan Zakat, Infak dan Sedekah (ZIS) Untuk Meningkatkan Ekonomi Duafa (Studi Kasus di Lembaga Amil Zakat Nurul Hayat Cabang Medan). At-Tawassuth, Vol. IV No. 1.

[12] Tho'in, M., \& Marimin, A. (2019). Faktor-Faktor Yang Mempengaruhi Minat Muzakki Dalam Membayar Zakat. Proceeding Seminar Nasional \& Call For Papers.

[13] Mirawati, N., Tanjung, H., \& Arif, S. (2019). Analisis Faktor-Faktor Yang Mempengaruhi Minat Muzakki Untuk Berzakat di Baznas Kota Bogor,. Jurnal Dinamika Penelitian: Media Komunikasi Penelitian Sosial Keagamaan, Vol. 19 No. 1.

[14] Rakhmania, N. A. (2018). Pengaruh Pendapatan, Religiusitas, Kepercayaan dan Pengetahuan Terhadap Minat Muzakki Mengeluarkan Zakat Melalui Lembaga Amil Zakat di Kota Malang. Skripsi Universitas Brawijaya Malang.

[15] Rinaldi, S. F., \& Hidayah, Z. (2017). Metodologi Penelitian dan Statistik. Jakarta: Pusat Pendidikan Sumber Daya Manusia Kesehatan Badan Pengembangan dan Pemberdayaan Sumber Daya Manusia Kesehatan.

[16] Saaty, T. L. (2008). Decision Making with the Analytic Hierarchy Process. Int. Journal Services Sciences, Vol.1 No. 1.

[17] Tho'in, M., \& Marimin, A. (2019). Faktor-Faktor Yang Mempengaruhi Minat Muzakki 
Dalam Membayar Zakat. Proceeding Seminar Nasional \& Call For Paper.

[18] Triyawan, A., \& Aisyah, S. (2016). Islamic Economics Journal, Vol. 2 No. 1.

[19] Uyun, Q. (2015). Zakat, Infaq, Shadaqah dan Wakaf Sebagai Konfigurasi Filantropi Islam. Islamuna, Vol. 2 No. 2.

[20] Walidin, W., Saifullah, \& Tabrani. (2015). Metodologi Penelitian Kualitatif \& Grounded Theory. Banda Aceh: FTK Ar-Raniry Press. 